\title{
ANALISIS SISTEM DAN PROSEDUR PENGELUARAN TENTANG PENERBITAN SURAT PERINTAH MEMBAYAR LANGSUNG (SPM-LS) PADA BADAN PENGELOLA PAJAK DAN RETRIBUSI DAERAH KOTA MANADO
}

\author{
Reza Arfansyah Suneth ${ }^{1}$, Harijanto Sabijono ${ }^{2}$, Lidia Mawikere ${ }^{3}$ \\ ${ }^{1,2,3}$ Jurusan Akuntansi, Fakultas Ekonomi dan Bisnis, Universitas Sam Ratulangi, Jl. Kampus Bahu, Manado, \\ 95115, Indonesia \\ E-mail : reza.suneth@gmail.com
}

\begin{abstract}
This study discusses the Operating System and its Completion (SPM-LS) at the Regional Tax and Retribution Agency of Manado City. This research depends on the procedures and procedures on how to quickly (SPM-LS) because of the function of SPM-LS is the activity of work order from SKPD that is important to be studied. The purpose of this study is to find out how the system and procedures about the warrant that is in the agency tax and levy manado city and whether the system and procedures about the warrant is in conformity with SE.900 / 316 / BAKD. The method used in this research is descriptive, with qualitative approach. Results of research. Plans and payments. It is expected that the Regional Tax and Retribution Board of Manado City can improve and implement the system and procedures on Manado Regional Tax and Retribution Board of Manado City.
\end{abstract}

Keywords: Letter pay Publishing, BP2RD, SPM-LS

\section{PENDAHULUAN}

Sistem pemerintahan dari sistem pusat sebagai sistem otonomi daerah sudah memberi dampak yang besar pada sistem penyelenggaraan pemerintahan dan ruang lingkup kinerja. Hal ini juga memberi dampak pada pengaturan sistem keuangan pemerintahan di daerah. Otonomi daerah merupakan pembagian kekuasaan yang diberikan oleh pemerintah pusat kepada pemerintah daerah untuk mengurus dan mengatur daerahnya.hal ini memberi akibat pada pengaturan sistem keuangan pemerintahan di daerah. Otonomi daerah mengharuskan pemerintah daerah untuk memberikan pelayanan publik yang berdasarkan asas-asas pelayanan publik yang meliputi transparansi, akuntabilitas, kondisional, partisipatif, kesamaan hak, serta keseimbangan hak dan kewajiban demi tercapainya pemerintahan yang baik (Laotongan 2015:2).

Peraturan Menteri Dalam Negeri Nomor 13 tahun 2006 pasal 232 ayat (1) sistem Akuntansi pemerintahan Daerah sekurang-kurangnya meliputi : prosedur akuntansi penerimaan kas, dan prosedur akuntansi asset tetap atau barang milik daerah, dan prosedur akuntansi selain kas. Penerbitan surat perintah membayar (SPM) merupakan bagian dari sistem dan prosedur pengeluaran kas, proses penerbitan SPM adalah tahapan penting dalam penatausahaan pengeluaran yang merupakan tahap lanjut dari proses pengajuan surat permintaan pembayaran (SPP). Proses ini dimulai dari SPM yang diajukan baik dari segi kelengkapan dokumen maupun kebenaran pengisiannya. Surat perintah membayar (SPM) dapat diterbitkan jika pengeluaran yang diminta tidak melebihi penganggaran yang tersedia dan didukung dengan kelengkapan dokumen sesuai peraturan perundangan (Permendagri No 13. Tahun 2006). Mengelola keuangan dan aset daerah perlu adanya pengawasan internal yang memadai, hal ini diatur dalam Peraturan Pemerintah No. 60 Tahun 2008 tentang Sistem Pengendalian Internal Pemerintah.Sistem pengendalian internal pemerintah merupakan proses yang integral pada tindakan dan kegiatan yang dilakukan secara terus menerus oleh pimpinan dan seluruh pegawai, pengamanan aset negara/daerah dan ketaatan terhadap peraturan perundang-undangan (PP No. 60 Tahun 2008). Organisasi sektor publik yang 
bergerak di bidang pendapatan daerah, Dinas Pendapatan Daerah Kota Manado Yang Menganti Nama Menjadi Badan Pengelola Pajak Dan Retribusi Daerah Kota Manado menerapkan mekanisme pencatatan dan pengelolaan keuangan yang juga membahas tentang pengeluaran kas. Badan Pengelola Pajak Dan Retribusi Daerahyang merupakan salah satu satuan kerja yang berada di Kota Manado dalam mengelola keuangan daerah harus memiliki sistem dan prosedur pengeluaran tentang penerbitan SPM sebagai salah satu tindakan preventif terhadap adanya penyelewengan dan penyalahgunaan dana berdasarkan SE.900/316/BAKD.

\section{TINJAUAN PUSTAKA}

\subsection{Akuntansi Sektor Pubik}

Kegiatan jasa yang bersifat keuangan dari entitas pemerintah guna pengambilan keputusan ekonomi dari pihak tertentu untuk berbagai alternatif arah tindakan. Ini berkaitan erat dengan penerapan dan perlakuan akuntansi pada domain publik.Domain publik sendiri memiliki wilayah yang lebih luas dan kompleks dibandingkan dengan sektor swasta. (Halim 2014: 97)

\subsection{Sistem Akuntansi Pemerintahan}

Menurut Permendagri Nomor 13 tahun 2006 pasal 232 ayat 1 sistem akuntansi pemerintahan daerah sekurang-kurangnya meleputi : Prosedur Akuntansi penerimaan kas, prosedur pengeluaran kas, prosedur akuntansi asset tetap/barang milik daerah dan prosedur akuntansi selain kas. Permendagri No. 64 tahun 2013 pasal 1 ayat 8 pengertian system akuntansi pemerintah daerah (SAPD) adalah rangkaian system sistematik dari prosedur, penyelenggara, peralatan dan elemen lain untuk mewujudkan fungsi akuntansi sejak analisis transaksi sampai dengan pelaporan keuangan dilingkungan organisasi pemerintah daerah.

\subsection{Sistem Pengendalian Internal}

Menurut (Septyansari 2015: 3) pengendalian internal merupakan penyusunan dari kegiatan perusahaan rencana untuk mengelola danauntuk menghasilkan informasi yang diperlukan. Sistem Pengendalian Internal merupakan proses yang dirancang untuk memberikan keyakinan yang memadai mengenai pencapaian tujuan pemerintah daerah yang tercermin dari keandalan laporan keuangan, efisiensi dan efektivitas pelaksanaan program dan kegiatan serta di patuhinya peraturan perundang-undangan.

\subsection{Kerangka Hukum}

Surat perintah membayar diterbitkan oleh pegguna anggaran/kuasa pengguna anggaran setelah surat perintah pembayaran dinyatakan lengkap dan sah, SPM ini diterbitkan pada kuasa BUD dalam rangka penerbitan surat pencairn dana (SP2D). Peraturan Menteri Dalam Negeri 13/2006 memberikan panduan pelaksanaan penerbitan SPM dokumendokumen yang diperlukan, dan pelaksanaan penatausahaan terkait pengeluaran perintah membayar.

\subsection{Surat Perintah Membayar (SPM)}

Beberapa dokumen yang diterbitkan oleh pengguna Anggaran/Kuasa Pengguna Anggaran atau pejabat lain yang ditunjuk untuk mencairkan dana yang bersumber dari DIPA atau dokumen lain yang dipersamakan. SPM diproses menggunakan aplikasi SPM yang dikembangkan oleh Direktorat Sistem perbendaharaan Ditjen Perbendaharaan. SPM berlaku sebagai surat perintah kepada KPPN sebagai kuasa BUN didaerah untuk mencairkan dana APBN.

\subsection{Langkah-langkah Teknis \\ 2.6.1 Surat Penyediaan Dana (SPD)}

1. Kuasa BUD

Dalam kegiatan ini, kuasa BUD mempunyai tugas sebagai berikut.

1) Memeriksa DPA-SKPD yang ada di Perbup APBD 
2) Memeriksa anggaran kas pemerintah khususnya data per SKPD

3) Menyiapkan draft SPD Mendistribusikan SPD kepada para Pengguna Anggaran

2. PPKD

Dalam kegiatan ini, PPKD mempunyai tugas sebagai berikut.

1) Meneliti draft SPD yang diajukan Kuasa BUD

2) Melakukan otorisasi SPD

3. Pengguna Angaran

Dalam kegiatan ini, PA mempunyai tugas sebagai berikut.

1) Memberikan keterangan yang diperlukan oleh Kuasa BUD

2) Mengarsipkan SPD yang diterima

\subsubsection{Surat Persetujuan Pembayaran (SPP)}

PPK SKPD meneliti kelengkapan dokumen SPP-UP/GU/TU/LS yang dilampirkan. Kelengkapan dokumen tersebut mengacu kepada daftar dokumen yang telah dipersyaratkan dalam permendagri 13/2006 dan telah dinyatakan kembali dalam proses Khusus untuk SPPGU dan SPP-TU, kelengkapan dokumen tersebut mencakup juga SPJ yang telah disahkan.

Selanjutnya, dengan melihat DPA SKPD apakah sudah sesuai yang terkait serta batasan jumlah dalam SPD yang terkait. Apabila telah dinyatakan lengkap, maka PPK-SKPD akan membuat rancangan SPM.

\subsubsection{Langkah 3 Surat Perintah Membayar (SPM)}

Rancangan SPM ini dibuat dua rangkap, satu dokumen akan deregister dalam SPMUP/GU/TU/LS, sementara dokumen aslinya dikirim kepada pengguna anggaran diotorisasi. Penerbitan SPM paling lambat dua hari sejak SPP-UP/GU/TU/LS diterimah. SPM yang telah diotorisasi dikirimkan kepada kuasa PUD dilengkapi dengan dokumen-dokumen sebagai berkut :

1. Untuk SPM UP

1) Surat pernyataan tanggung jawab pengguna anggaran/kuasa pengguna anggaran.

2. Untuk SPM GU

1) Surat pernyataan tanggung jawab pengguna anggaran/kuasa pengguna anggaran.

2) Surat pengesahan pertanggung jawaban bendehara pengeluaran periode sebelumnya.

3) Ringkasan pengeluaran perincina objek yang disertai dengan bukti-bukti pengeluaran yang sah dan lengkap.

4) Bukti atas penyetoran PPN/PPh.

3. Untuk SPM-TU

1) Surat pernyataan langsung tanggung jawab pengguna anggran/kuasa pengguna anggaran.

4. Untuk SPM-LS

1) Surat pernyataan tanggung jawab pengguna anggaran/kuasa pengguna anggaran.

2) Bukti yang sah dari pengeuaran dan sudah lengkap sesuai dengan kelengkapan persyaratan yang ditetapkan dalam peraturan perundang-undangan.

\subsection{Penelitian terdahulu}

Penelitian yang dilakukan oleh Laotongan Ray Risiano Imanuel (2015), tentang Analisis Pelaksanaan Sistem Dan prosedur Akuntansi Pengeluaran kas pada Dinas kesehatan Kota Manado, menyatakan bahwa sistem dan prosedur pengeluaran kas pada Dinas kota Manado sudah sesuai dengan peraturan yang berlaku

\section{METODE PENELITIAN}

\subsection{Jenis Penelitian}

(Sedarmayati \& Syarifudin 2013: 25) menyatakan metode penelitian adalah pembahasan mengenai konsep teori berbagai metode, kelebihan dan kelemahannya, yang dalam karya ilmiah dilanjutkan dengan pemilihan metode yang digunakan. Jenis penelitian 
yang digunakan adalah penelitian deskriptif, yaitu penelitian yang dilakukan untuk mengetahui dan menjelaskan variable yang diteliti dalam suatu situasi (Sekaran 2014: 58)

\subsection{Waktu dan Tempat Penelitian}

Penelitian ini dilaksanakan Di Badan Pengelola Pajak Dan Retribusi Daerah Kota Manado Jalan Balai kota 2, Tikala Kumaraka, Kota Manado, Sulawesi Utara. Penelitian ini dilakukan dalam kurun waktu 2 bulan mulai dari bulan agustus sampai dengan bulan september tahun 2017

\subsection{Prosedur Penelitian}

Dalam prosedur penelitian ini penulis melakukan tahapan-tahapan penelitian yang berhubungan masalah yang diteliti. Tahapan-tahapan tersebut adalah sebagai berikut:

1. Mengidentifikasi permasalahan yang signifikan untuk dipecahkan melalui metode deskriptif.

2. Merumuskan permasalahan yang jelas agar dalam penelitian ini dapat terarah pada masalah yang ada di badan pengelola pajak dan retribusi daerah kota manado. Perumusan yang jelas dapat memberikan kemudahan dalam menyelesaikan penelitian ini

3. Menentukan tujuan penelitian yang bertujuan untuk mengevaluasi pelaksanaan tentang sistem dan prosedur penerbitan surat perintah membayar langsung (SPM-LS)

4. Menentukan manfaat penelitian, penentuan manfaat penelitian akan memberi manfaat bagi pengembangan khususnya bidang ilmu pengetahuan dan dapat menjadi referensi bagi peneliti lainnya yang berminat untuk mengkaji dalam bidang yang sama dan ruang lingkup yang berbeda dan bias juga menjadi masukan bagi dinas pendapatan daerah kota manado dalam meningkatkan pengawasan tentang sistem dan prosedur surat perintah membayar langsung (SPM-LS)

5. Mengumpulkan informasi mengenai gambaran umum perusahaan, pengumpulan informasi mengenai gambaran umum perusahaan yang akan diteliti di badan pengelola pajak dan retribusi daerah kota manado mendapat satu kemudahan dalam pengumpulan informasi ini karena peneliti dibantu staf dari instansi dinas tersebut, pengumpulan informasi ini berguna untuk dapat memberikan penjelasan yang jelas atas latar belakang berdirinya instansi ini sampai fungsi dari instansi tersebut

6. Mengumpulkan data di badan pengelola pajak dan retribusi daerah kota manado tentang surat perintah membayar langsung (SPM-LS) pada pengumpulan data ini terjadi kesulitan untuk mendapatkan data yang diminta oleh peneliti dari pihak instansi yang diteliti, kesulitan tersebut membatasi peneliti dalam penyelesaian penelitian ini. Tetapi dalam beberapa hari kemudian pihak instansi menghubungi kembali para peneliti untuk mengambil data yang diajukan oleh peneliti. Sehingga instansi mendapatkan hasil penelitian tersebut untuk menjadi bahan evaluasi untuk instansi badan pengelola pajak dan retribusi daerah kota manado

7. Mengevaluasi sistem dan prosedur surat perintah membayar langsung (SPM-LS) apakah sudah sesuai dengai Peraturan Menteri Dalam Negeri No. 13 Tahun 2006.

8. Membuat kesimpulan berdasarkan hasil penelitian mengenai sistem dan prosedur surat perintah membayar langsung (SPM-LS) berdasarkan Peraturan Menteri Dalam Negeri No. 13 Tahun 2006

9. Memberikan saran bagi instansi badan pengelola pajak dan retribusi daerah kota manado untuk dapat meningkatkan kualitas dalam pelaksanaan penerbitan surat perintah membayar langsung (SPM-LS) dan dapat menjadi evaluasi di instansi badan pengelola pajak dan retribusi daerah kota manado

\subsection{Metode Analisis}

Dalam penelitian ini digunakan teknik analisis deskriptif kualitatif tentang pelaksanaan penerbitan surat perintah membayar langsung (SPM-LS) dan menguraikan datadata yang diperoleh dari badan pengelola pajak dan retribusi daerah kota manado. Data 
tersebut kemudian dibandingkan dengan landasan teori yang ada dan dilakukan pembahasan masalah sehingga bisa ditarik kesimpulan mengenai dsistem dan prosedur penerbitan surat perintah membayar langsung (SPM-LS) di Badan pengelola Pajak Dan Retribusi Daerah Kota Manado.

\section{HASIL ANALISIS DAN PEMBAHASAN \\ 4.1 Hasil analisis}

4.1.1 Sistem dan Prosedur pengeluaran tentang Surat Perintah Membayar Langsung (SPM-LS) pada Badan Pengelola Pajak dan Retribusi Daerah Kota Manado

Prosedur akuntansi Belanja lansung, yaitu serangkaian proses baik manual maupun secara komputerisasi, dimulai dari pencatatan transaksi serta pengikhtisarannya sampai dengan pelaporan keuangan dalam rangka mempertanggungjawabkan pelaksanaan APBD yang terkait dengan Belanja. Sistem dan prosedur belanja langsung yang diterapkan pada (BP2RD) Badan Pengelola Pajak dan Retribusi Daerah Kota Manado dalam pelaksanaan Belanja Langsung yaitu sebagai berikut.

\section{Pengajuan Surat Penyediaan Dana (SPD)}

Digunakan untuk menyediakan dana bagi tiap-tiap SKPD dalam periode waktu tertentu. Informasi SPD yaitu untuk menunjukkan dengan jelas alokasi dari setiap kegiatan tetapi tidak harus dibuat SPD untuk kegiatan secara tersendiri. PPKD selaku BUD membuat SPD nya tanpa menunggu DPA disahkan.

\section{Pengajuan Surat Permintaan Pembayaran (SPP)}

Bendahara pengeluaran Badan Pengelola Pajak dan Retribusi Daerah Kota Manado mengajukan SPP dalam rangka melaksanakan belanja. Dokumen SPP ini berupa Uang Persediaan (SPP-UP), Ganti Uang (SPP-GU), Tambah Uang (SPP-TU) dan Langsung (SPPLS). Dalam Peraturan Pemerintah, SPP yang diajukan ini harus diverifikasi oleh PPK seperti yang diatur dalam Permendagri Nomor 55 tahun 2008.

a. Langsung (SPP-LS)

SPP-LS digunakan untuk pembayaran langsung kepada pihak ketiga dengan jumlah yang telah di tetapkan.Pembayaran langsung digunakan untuk belanja pegawai berupa gaji dan tunjangan, serta belanja untuk pengadaan barang dan/atau jasa.

1. LS untuk pembayaran gaji dan tunjangan

Bendahara menyiapkan dokumen-dokumen seperti salinan SPD, draft surat pernyataan pengguna anggaran, dokumen-dokumen pelengkap daftar gaji, lampiran lain yang diperlukan.

2. LS untuk pengadaan barang dan/atau jasa

Bendahara menyiapkan dokumen-dokumen seperti, salinan SPD, draf surat pernyataan pengguna anggaran, dokumen-dokumen terkait kegiatan yang dalam hal ini disiapkan oleh PPTK, dan lampiran lain yang diperlukan. Dokumen-dokumen yang disiapkan bendahara pengeluaran Badan Pengelola Pajak dan Retribusi Daerah Kota Manado untuk pengajuan SPP-LS ini sudah sesuai Permendagri Nomor 55 Tahun 2008.

proses pengajuan Surat Permintaan Pembayaran Langsung adalah sebagai berikut:

1. Pengguna anggaran menyerahkan SPD kepada Bendahara dan PPK SKPD

2. Sesuai SPD dan SPJ, Bendahara pengeluaran mengeluarkan SPP-LS beserta dokumen lainnya yang terdiri dari:
a. Surat pengantar SPP-LS
b. Ringkasan SPP-LS
c. Rincian SPP-LS
d. Lampiran
a) Pembayaran gaji induk 

b) Gaji susulan
c) Gaji terusan
d) Dan lain lain

3. Bendahara Pengeluaran menyerahkan SPP-LS beserta dokumen lain kepada PPK SKPD

4. SPP-LS yang dinyatakan lengkap akan dibuatkan rancangan SPM oleh PPK SKPD. Rancangan SPM ini kemudian diberikan PPK SKPD kepada pengguna anggaran untuk diotorisasi.

5. Apabila SPP-LS tidak lengkap, PPK SKPD akan menerbitkan Surat penolakan SPM. Penolakan SPM paling lambat 1 hari kerja sejak SPP-LS diterima.

\section{Pengajuan Surat Perintah Membayar Langsung (SPM-LS)}

Proses dimulai pada saat pengujian Surat Perintah Membayar Secara Langsung yang diajukan baik dari segi kelengkapan dokumen maupun kebenaran pengisiannya. Surat Perintah membayar Langsung diterbitkan ketika pengeluaran yang diminta tidak melebihi pagu anggaran yang tersedia dan didukung dengan kelengkapan dokumen sesuai peraturan perundangan.

Prosedur pengajuan SPM-LS dapat dijelaskan sebagai berikut:

Pengguna anggaran menyerahkan SPD kepada Bendahara dan PPK SKPD.

1. Berdasarkan SPD dan SPJ, Bendahara membuat SPP-GU beserta dokumen lainnya, yang terdiri dari:
a. Surat Pengantar SPP-LS
b. Ringkasan SPP-LS
c. Rincian SPP-LS
d. Lampiran
a) Pembayaran gaji induk
b) Gaji susulan
c) Kekurangan gaji
d) Gaji terusan
e) Dan lain-lain

e. Surat Pernyataan Pengguna Anggaran

f. Lain-lain lampiran (daftar secara rinci rencana pemakaian dana sampai pada jenis belanja)

2. Bendahara menyerahkan SPP-LS beserta dokumen lain kepada PPK SKPD

3. SPP-LS yang dinyatakan lengkap akan dibuatkan Rancangan SPM oleh PPK SKPD.

4. Rancangan SPM kemudian diberikan PPK SKPD kepada Pengguna Anggaran untuk diotorisasi

5. Jika SPP-LS dinyatakan tidak lengkap, maka PPK SKPD akan menerbitkan Surat Penolakan Penerbitan SPM. Penolakan SPM paling lambat 1 hari kerja sejak SPP-LS diterima

6. Surat Penolakan Penerbitan SPM diberikan kepada Bendahara, Bendahara melakukan penyempurnaan SPP-LS. Kemudian diserahkan kembali kepada PPK SKPD untuk diteliti kembali.

Sistem dan Prosedur pengeluaran tentang Surat Perintah Membayar (SPM-LS) terbagi menjadi 2 laporan pertanggungjawaban, yaitu sebagai berikut.

1) Pertanggungjawaban Administratif

Ini seperti SPJ (surat pertanggungjawaban) yang menggambarkan jumlah Anggaran, realisasi, dan sisa pagu anggaran, baik secara akumulatif maupun per kegiatan. SPJ bendahara pengeluaran merupakan penggabungan dengan SPJ bendahara pengeluaran pembantu.SPJ ini dilampiri dengan dokumen berikut.

1. Buku Kas Umum

2. Laporan penutupan kas 
3. SPJ Bendahara Pengeluaran Pembantu

Pertanggungjawaban ini juga harus dilampiri bukti setoran sisa uang persediaan ke rekening Kas Umum Daerah.Hal-hal yang dipersiapkan oleh Bendahara Pengeluaran Badan Pengelolaan Pajak dan Retribusi Daerah Kota Manado yaitu sebagai berikut.

1. Menyiapkan laporan penutupan kas

2. Melakukan rekapitulasi jumlah-jumlah belanja dan hal-hal terkait berdasarkan BKU dan Buku Pembantu BKU lainnya, serta Buku Pembantu Rincian Objek

3. Bendahara pengeluaran membuat SPJ, dengan rekapitulasi dan penggabungan itu

4. Setelah mendapatkan verifikasi, pengguna anggaran menandatanganinya sebagai bentuk pengesahan.

Dalam pertanggungjawaban administratif ini, bendahara pengeluaran Badan Pengelolaan Pajak dan Retribusi Daerah Kota Manado sudah membuat SPJ sesuai dengan peraturan dan sesuai dengan permendagri 55 Tahun 2008 yang mengharuskan bendahara menyampaikan SPJ paling lambat tanggal 10 bulan berjalan.

1. Pertanggungjawaban Fungsional

Pertanggungjawaban fungsional tersebut berupa SPJ yang merupakan penggabungan dengan SPJ bendahara pengeluaran pembantu.SPJ ini dilampiri dengan dokumen berikut.

1. Laporan penutupan kas

2. SPJ bendahara pengeluaran pembantu

Pertanggungjawaban ini harus dilampiri bukti setoran sisa uang persediaan ke rekening Kas Umum Daerah. Secara keseluruhan laporan pertanggungjawaban administratif dan fungsional bendahara pengeluaran Badan Pengelola Pajak dan Retribusi Daerah Kota Manado sudah sesuai dengan peraturan yang berlaku.

\subsection{Pembahasan}

\subsubsection{Analisis Sistem dan Prosedur Pengeluaran tentang Penerbitan Surat Perintah Membayar Langsung (SPM-LS) pada Badan Pengelola Pajak dan Retribusi Daerh Kota}

Sistem dan Prosedur Penerbitan Surat Perintah membayar langsung (SPM-LS) pada Badan Pengelola Pajak Dan Retribusi Daerah Kota Manado telah sesuai dengan prosedur perundangan yaitu SE.900/316/BAKD yang merupakan Surat Edaran dari Menteri Dalam Negeri dalam rangka implementasi Permendagri Nomor 13 Tahun 2006.

Peraturan daerah yang berkaitan dengan prosedur harus dirancang sedemikian rupa dan secara hati-hati supaya antara ketentuan satu dengan yang lainnya dapat saling berkesesuaian secara efektif dan efisien. Sistem dan Prosedur Akuntansi Pengeluaran Kas terdiri dari 4 sub sistem akuntansi yaitu sebagai berikut.

1. Sub Sistem Akuntansi Pengeluaran Kas Uang Persediaan (UP)

2. Sub Sistem Akuntansi Pengeluaran Kas Ganti Uang Persediaan (GU)

3. Sub Sistem Akuntansi Pengeluaran Kas Tambahan Uang Persediaan (TUP)

4. Sub Sistem Akuntansi Pengeluaran Kas Langsung (LS)

Sebagai langkah pertama dari kegiatan Pengeluaran Kas dilakukanberdasarkan Surat Penyediaan Dana (SPD) yang adalah dokumen yang dibuat oleh BUD yang menyatakan tersedianya dana untuk melaksanakan kegiatan sebagai dasar penerbitan SPP-LS. Berdasarkan SPD yang diterima, bendahara pengeluaran mengajukan SPP-LS kepada pengguna anggaran melalui PPK-SKPD.Dalam hal dokumen SPP-LS dinyatakan lengkap, pengguna anggaran akan menerbitkan SPM-LS. Apabila dokumen SPP-LS tidak lengkap maka akan diterbitkan surat penolakan SPM-LS oleh PPK-SKPD. Persiapan Surat Perintah Membayar dilaksanakan oleh PPK SKPD dan ditandatangani oleh pengguna anggaran.SPMLS yang telah diterbitkan oleh pengguna anggaran diajukan kepada BUD untuk penerbitan SP2D. Bendahara Umum Daerah mempunyai wewenang untuk menolak pencairan dana jika SPM yang diterbitkan oleh pengguna anggaran belum memenuhi persyaratan yang 
ditetapkan.

\section{Pelaksana Penerbitan Surat Penyediaan Dana (SPD)}

Sebagaimana diatur dalam SE.900/316/BAKD, SPD adalah Surat Penyediaan Dana yang dibuat oleh BUD (Bendahara Umum Daerah) dalam rangka manajemen kas daerah. (BP2RD) Badan Pengelola Pajak dan Retribusi Daerah Kota Manado telah melaksanakan sesuai dengan SE.900/316/BAKD tentang Pedoman Sistem dan Prosedur Penatausahaan dan Akuntansi, Pelaporan dan Pertanggungjawaban Keuangan Daerah. Surat Penyediaan Dana berfungsi menyediakan dana untuk tiap-tiap SKPD dalam periode waktu tertentu. Informasi dalam SPD menunjukkan secara jelas alokasi tiap kegiatan, dimana pihak yang terkait yaitusebagai berikut.

1. Kuasa BUD

Dalam kegiatan ini, kuasa BUD mempunyai tugas sebagai berikut:

a. Menganalisa DPA SKPD yang ada di database

b. Menganalisa anggaran kas pemerintah khususnya data per SKPD

c. Menyiapkan draft SPD

d. Mendistribusikan SPD kepada Pengguna Anggaran

2. PPKD

Dalam kegiatan ini PPKD mempunyai tugas sebagai berikut:

a. Meneliti draft SPD yang diajukan Kuasa BUD

b. Melakukan otorisasi SPD

3. Pengguna Anggaran

Dalam kegiatan ini PA mempunyai tugas sebagai berikut:

a. Memberikan keterangan yang diperlukan oleh Kuasa BUD

b. Mengarsipkan SPD yang diterima

\section{Penerbitan Surat Permintaan Pembayaran Langsung (SPP-LS)}

Bendahara Pengeluaran berdasarkan SPD dan SPJ membuat SPP LS kepada pengguna anggaran/kuasa pengguna anggaran melalui pejabat penatausahaan keuangan SKPD (PPKSKPD).SPP langsung (LS) dipergunakan untuk pembayaran gaji tiap-tiap SKPD. Sehubungan dengan penerbitan SPP, hal pertama yang dilakukan oleh bendahara pengeluaran adalah mengajukan SPP (Surat Permintaan Pembayaran) kepada pengguna anggaran melalui Pejabat Penatausahaan Keuangan (PPK) SKPD. Jika Surat Permintaan Pembayaran sudah diverifikasi oleh pengguna anggaran, maka tahapan selanjutnya adalah penerbitan Surat Perintah Membayar (SPM) oleh Pejabat Penguna Anggaran.

Mekanisme ini sudah sesuai dengan SE.900/316/BAKD. Pembuatan SPP-LS dilampiri dengan daftar rincian pembayaran gaji induk sampai pada jenis gaji terusan.Pihak yang terkait dengan pengajuan SPP-LS pada Badan Pengelola Pajak dan Retribusi Daerah Kota Manado daerah Kota Manado sudah sesuai dengan aturan yang ada dalam SE.900/316/BAKD yaitu sebagai berikut.

1. Bendahara Pengeluaran

Dalam kegiatan ini bendahara pengeluaran mempunyai tugas sebagai berikut:

a. Mempersiapkan dokumen SPP beserta lampiran-lampirannya

b. Mengajukan SPP kepada PPK-SKPD

2. PPK-SKPD

Dalam kegiatan ini PPK-SKPD mempunyai tugas, yaitu menguji kelengkapan dan kebenaran SPP-LS yang diajukan oleh bendahara pengeluaran.

\section{Penerbitan Surat Perintah Membayarlangsung (SPM-LS)}

Penerbitan SPM merupakan tahap penting dalam penatausahaan pengeluaran sebagai tahap lanjutan dari proses pengajuan SPP-LS. Dalam hal ini Badan Pengelola Pajak Dan Retribusi daerah Kota Manado menerbitkan SPM-LS sejalan dengan ketentuan dalam SE.900/316/BAKD dimana SPM-LS dapat diterbitkan jika pengeluaran yang diminta tidak 
melebihi pagu anggaran yang tersedia dan didukung dengan kelengkapan dokumen sesuai peraturan perundangan sedangkan waktu pelaksanaan penerbitan SPM-LS diterbitkan paling lambat 2 hari sejak SPP-LS diterima. Apabila ditolak, dikembalikan paling lambat 1 hari sejak SPP-LS diterima.

Penerbitan SPM-LS adalah otoritas Pejabat Pengguna Anggaran (PPA).Dengan demikian tanda tangan dokumen SPM-LS dilakukan oleh pengguna anggaran yang bersangkutan sebagai sebuah pernyataan penggunaan anggaran di lingkup SKPDnya. SPMLS yang telah ditandatangani kemudian diajukan kepada bendahara umum daerah (BUD) sebagai otoritas yang akan melakukan pencairan dana.

Pihak yang terkait dalam penerbitan SPM-LS sebagai berikut :

1. PPK-SKPD

Dalam kegiatan ini, PPK SKPD memiliki tugas sebagai berikut:

a. Menguji SPP-LS beserta kelengkapannya

b. Membuat rancangan SPM-LS atas SPP-LS yang telah diuji kelengkapan dan kebenarannya dan mengajukannya ke Pengguna Anggaran

c. Menerbitkan Surat Penolakan SPM-LS bila SPP-LS yang diajukan oleh Bendahara SKPD tidak lengkap

d. Membuat register SPM-LS

2. Pengguna Anggaran

Dalam kegiatan ini, Pengguna Anggaran memiliki tugas sebagai berikut:

a. Mengotorisasi dan Menerbitkan SPM-LS

b. Menandatangani SPM-LS

c. Mengotorisasi Surat Penolakan SPM-LS yang diterbitkan PPK SKPD bila SPP-LS yang diajukan bendahara SKPD tidak lengkap.

Berkaitan dengan hal itu pemerintah juga sekiranya harus memperhatikan lingkungan akuntansi, termasuk kondisi dan kemampuan para penggunanya. Tetapi pemerintah daerah juga perlu mengantisipasi dan mempersiapkan secara memadai hal-hal yang menjadi indikator keberhasilan dari penerapan sistem pengelolaan keuangan daerah yang baru, antara lain organisasi, SDM, sarana dan prasarana, dana dan kebijakan daerah. Selain itu pemerintah pusat juga harus mendukung dengan menerbitkan peraturan perundangan berupa peraturan pemerintah yang bersifat "Omnibus Regulation", yaitu peraturan perundangan yang dapat mensinkronisasikan berbagai peraturan perundangan tentang pengelolaan keuangan daerah sehingga segala peraturan perundangan terkait dengan pengelolaan keuangan daerah tersebut semaksimal mungkin bermuara pada satu peraturan pemerintah.

Berdasarkan hasil penelitian yang dilakukan oleh penulis, dapat dikatakan Badan Pengelola Pejaka dan Retribusi Daerah Kota Manado sudah melakukan pengelolaan keuangan sesuai dengan peraturan yang berlaku meskipun masih terdapat beberapa kendala yang dihadapi oleh bendahara dalam melakukan penatausahaan dan penyusunan laporan pertanggungjawaban serta penyampaiannya. Sehubungan dengan hal itu pemerintah Kota Manado terus berusaha untuk menciptakan "good governance" dengan mengikuti berbagai seminar-seminar dan pelatihan yang diselenggarakan oleh pemerintah.

\section{KESIMPULAN DAN SARAN \\ 5.1 Kesimpulan}

Berdasarkan hasil penelitian dan pembahasan yang telah dilakukan di Badan Pengelola Pajak Dan Retribusi Daerah Kota Manado maka dapat diambil kesimpulan bahwa sistem dan prosedur Tentang Surat Perintah Membayar Langsung (SPM-LS) pada Badan Pengelola Pajak Dan Retribusi Daerah Kota Manado sudah sesuai dengan SE.900/316/BAKD, dalam sistem dan prosedur Pengeluaran Tentang Surat Perintah membayar Langsung (SPM-LS) pada Badan Pengelola Pajak Dan Retribusi Daerah Kota 
Manado telah didukung oleh dokumen-dokumen terkait seperti Surat Penyediaan Dana (SPD), Surat Permintaan Pembayaran (SPP) Dan Surat Perintah Membayar (SPM), serta dokumen transaksi untuk melengkapi prosedur pengeluaran kas. Dan aktivitas prosedur pengeluaran kas pada Badan Pengelola Pajak Dan Retribusi Daerah Kota Manado telah dilakukan sesuai dengan prosedur dimana ada pemisahan tugas yang jelas dan adanya pertanggungjawaban sesuai dengan SE.900/316/BAKD.

\subsection{Saran}

Adapun saran berdasarkan hasil penelitian dan pembahasan yang mungkin dapat dipertimbangkan sebagai masukan untuk dilaksanakan Badan Pengelola Pajak Dan Retribusi Daerah Kota Manado sebagai berikut :

1. Badan Pengelola Pajak Dan Retribusi Daerah Kota Manado dapat meningkatkan dan mempertahankan sistem dan prosedur pengeluaran Tentang Surat Perintah Membayar (SPM-LS) pada Badan Pengelola Pajak Dan Retribusi Daerah Kota Manado dan diharapkan untuk tetap mengikuti peraturan yang berlaku jika terjadi perubahan peraturan.

2. Badan Pengelola Pajak Dan Retribusi Daerah Kota Manado lebih banyak mengadakan sosialisasi dan bimbingan teknis tentang SE.900/316/BAKDterhadap sumber daya manusia yang telah ada khususnya di bidang akuntansi agar dapat meningkatkan kualitas sumber daya manusia sehingga akan berdampak positif pada sistem dan prosedur pengeluaran Tentang Surat Perintah Membayar Langsung (SPM-LS) pada Badan Pengelola Pajak Dan Retribusi Daerah Kota Manado Kota Manado.

\section{DAFTAR PUSTAKA}

Halim, Abdul \& Kusufi M Syam, 2014.Akuntansi Sektor Publik.Edisi 2.Salemba Empat. Jakarta

Laotongan, RaysianoImanuel, 2015.Analisis Pelaksanaan Sistem dan Prosedur Pengeluaran Kas Pada Dinas Kesehatan Kota Manado.Skripsi Fakultas Ekonomi dan Bisnis.Universitas Sam Ratulangi Manado.

Mahmudi, 2011.Akuntansi Sektor Publik. Penerbit UII Press. Yogyakarta.

Republik Indonesia. Peraturan Menteri Dalam Negeri Nomor 21 Tahun 2011 yang merupakan perubahan kedua atas Peraturan Menteri Dalam Negeri Nomor 13 Tahun 2006 Tentang Pedoman Pengelolaan Keuangan Daerah. Jakarta.

Republik Indonesia. Peraturan Menteri Dalam Negeri Nomor 64 Tahun 2013 Tentang Standar Akuntansi Berbasis Akrual Pada Pemerintah Daerah. Jakarta.

Republik Indonesia. Undang-Undang Nomor 17 Tahun 2003 Tentang Keuangan Negara. Jakarta

Republik Indonesia.Peraturan Pemerintah Nomor 58 Tahun 2005Tentang pengelolaan keuangan daerah. Jakarta.

Republik Indonesia.Peraturan Pemerintah Nomor 71 Tahun 2010Tentang Standar Akuntansi Pemerintahan.Jakarta.

Republik Indonesia. Peraturan Perundang-Undangan Nomor 33 Tahun 2004 tentang perimbangan keuangan antara pemerintah pusat dan pemerintah daerah

Sedarmayanti, Syarifudin, 2011. Metodologi penelitian, Mandar Maju, Bandung

Septyansari, Dita, 2015. Analisis Sistem dan Prosedur Pembelian Barang Lokal dan Pengeluaran Kas dalam Upaya Peningkatan Pengendalian Intern. Jurnal Administrasi Bisnis (JAD) Vol.28 No.2 November 2015.

Sakeran, Uma. 2014. Metodologi Penelitian Untuk Bisnis. Terjemahan Buku satu Edisi 4, Salemba Empat, Jakarta 
Jurnal Riset Akuntansi Going Concern 13(3), 2018, 194-204

Surat Edaran Menteri Dalam Negeri Nomor SE.900/316/BAKD Tahun 2007 Tentang Pedoman Sistem dan Prosedur Penatausahaan dan Akuntansi Pelaporan dan Pertanggungjawaban Keuangan Daerah. Jakarta. 